\title{
PENGUATAN MOTIVASI SHALAT DAN KARAKTER PESERTA DIDIK MELALUI PENDEKATAN PEMBELAJARAN KONTEKSTUAL PADA MATA PELAJARAN PENDIDIKAN AGAMA ISLAM
}

\author{
STRENGTHENING OF STUDENT MOTIVATION AND CHARACTER \\ THROUGH THE LEARNING APPROACH TO CONTEXTUAL LESSONS OF \\ ISLAMIC EDUCATION
}

\author{
Arsyad \\ Sekolah Tinggi Keguruan dan Ilmu Pendidikan (STKIP) Muhammadiyah \\ Bogor, Indonesia \\ Email: arsyaddjamaluddin@gmail.com \\ Wahyu Bagja Sulfemi \\ Sekolah Tinggi Keguruan dan Ilmu Pendidikan (STKIP) Muhammadiyah \\ Bogor, Indonesia \\ Email: wahyubagja@gmail.com
}

Tia Fajartriani

Sekolah Tinggi Keguruan dan Ilmu Pendidikan (STKIP) Muhammadiyah

Bogor, Indonesia

Email: fajartriani@gmail.com

\begin{abstract}
Abstrak
Penelitian dilaksanakan di Sekolah Menengah Pertama Negeri SeKecamatan Leuwiliang Kabupaten Bogor dengan populasi seluruh peserta didik kelas 7 dari 3 SMP Negeri di Kecamatan Leuwiliang yaitu SMP Negeri 1 Leuwiliang, SMP Negeri 2 Leuwiliang dengan, dan SMP Negeri 3 Leuwiliang dengan jumlah keseluruhan 390 Siswa. Jumlah sampel yang diambil $10 \%$ yaitu 40 orang dengan menggunakan teknik pengambilan sampel secara acak. Metode yang digunakan adalah metode deskriptif yaitu membuat deskriptif secara sistematis, faktual dan akurat mengenai fakat-fakta serta hubungan antar fenomena yang diselidiki, dengan tujuan untuk menguji hipotesis yang menyatakan ada atau tidak hubungan antara variabel bebas $\left(\mathrm{X}_{1}\right)$ dan $\left(\mathrm{X}_{2}\right)$ dengan variabel terikat (Y). Merujuk pada hasil uji regresi dan korelasi, maka terdapat pengaruh metode pembelajaran kontekstual pada PAI terhadap penguatan motivasi shalat. Terdapat pengaruh metode pembelajaran kontektusal pada PAI terhadap penguatan karakter peserta didik. Terdapat pengaruh metode pembelajaran kontekstual pada PAI terhadap penguatan motivasi shalat dan penguatan karakter peserta didik. Dengan pendekatan kontekstual dalam pembelajaran PAI di sekolah memberikan pengetahuan, penghayatan serta mendorong peserta didik untuk mempraktekkan dan mengaitkannya dalam kehidupan sehari-hari, karena merasakan hikmah dan manfaatnya dalam kehidupan nyata.
\end{abstract}

Kata Kunci: shalat, karakter, pembelajaran kontekstual, pendidikan agama Islam 
Arsyad, Wahyu Bagja Sulfemi, Tia Fajartriani: Penguatan Motivasi Shalat dan Karakter Peserta Didik melalui Pendekatan Pembelajaran Kontekstual pada Mata Pelajaran Pendidikan Agama Islam

\begin{abstract}
The study was conducted at the Leuwiliang Sub-District Middle School in Bogor Regency with a population of all 7th grade students from 3 Public Middle Schools in Leuwiliang Subdistrict namely 1 Leuwiliang State Middle School, Leuwiliang 2 Junior High School with, and Leuwiliang 3 Public Middle School with total number of 396 students. The number of samples taken was taken 10\%, namely 40 people using random sampling techniques. The method used is descriptive method that is making a systematic, factual and accurate descriptive of facts and the relationship between the phenomena investigated, with the aim of testing hypotheses that state whether or not there is a relationship between independent variables (X1) and (X2) with dependent variables (Y). Referring to the results of the regression test and correlation, then there is the influence of the contextual learning method on PAI towards strengthening prayer motivation. There is the influence of the contextual learning method on PAI towards strengthening the character of students. There is the influence of contextual learning methods on Islamic Education Educator on strengthening prayer motivation and strengthening the character of students. With a contextual approach to learning Islamic Education in schools providing knowledge, appreciation and encouraging students to practice and associate it in everyday life, because they feel the wisdom and benefits in real life.
\end{abstract}

Keywords: prayer, character, contextual learning, religious education

\title{
A. Pendahuluan
}

Pendidikan adalah beruasaha menjadikan potensi yang ada pada setiap diri peserta didik agar menghasilkan manusia yang berkualitas, yang memiliki pengetahuan dan moral dengan dilandasi oleh nilai-nilai keimanan dan ketakwaan. Pendidikan juga berberfungsi untuk membemtuk kepribadian. Konsep pendididkan juga tersebut menjadi rumusan tujuan pendidikan nasional sebagaimana ditegaskan dalam Undang-Undang RI. No. 20 tahun 2003 pasal 3. ${ }^{1}$ Tujuan pendidikan nasional tersebut diimplementasikan lebih jauh melalui tujuan Pendidikan Agama Islam (PAI) di SMP/MTs, yaitu untuk: (1) menumbuhkembangkan akidah melalui pemberian, pemupukan, dan pengembangan ilmu pengetahuan, pembiasaan, penghayatan, pengamalan, serta pengamalan peserta didik tentang agama Islam sehingga menjadi manusia muslim bertakwa pada Allah SWT. (2) memiliki kemampuan dalam beribadah dengan tuntuna syari'at Islam. (3) mewujudkan manuasia Indonesia yang taat beragama dan berakhlak mulia yaitu

\footnotetext{
${ }^{1}$ Undang-undang Republik Indonesia Nomor 20 Tahun 2003 tentang Sistem Pendidikan Nasional (Bandung; Fokus Media, 2003), 2
} 
manusia yang berpengetahuan, cerdas, produktif, jujur, adil, rajin beribadah, etis, berdisiplin, bertoleransi (tasamuh), menjaga keharmonisan secara personal dan sosial serta mengembangkan budaya Islam di sekolah. ${ }^{2}$

Hasil pembelajaran PAI tidak hanya dilihat dari ranah kognitif dan psikomotorik, tetapi juga dilihat dari hasil ranah afektif. Ketiga ranah tersebut saling berhubungan satu sama lain dan saling memperkuat, sehingga hasilnya akan melahirkan peserta didik yang taat dalam beribadah dengan karakter yang kuat sebagai seorang muslim yang taat pada Allah SWT. Penguatan akidah dan karakter melalui pembelajaran PAI merupakan proses pembentukan, transformasi, transmisi dan pengembangan potensi peserta didik agar beribadah dengan baik, bepikir baik, dan berprilaku baik sesuai nilai ajaran Islam.

Namun dalam impelementasinya, pembelajaran PAI di sekolah belum mampu mengarah pada substansi tujuan pembelajaran PAI tersebut, yaitu capaian pembelajaran yang mencerminkan keterpaduan antara aspek pengetahuan agama Islam (aspek kognitif), dan menjadi sarana transformasi norma dan nilai moral untuk membentuk sikap serta dapat berperan dalam mengendalikan prilaku. Berdasarkan studi pendahuluan yang dilakukan di Sekolah Menengah Pertama Negeri di Kecamatan Leuwiliang Kabupaten Bogor, hasil rekapitulasi nilai PAI siswa SMP Negeri Leuwiliang kelas delapan dengan rata-rata antara 75-85. Artinya bahwa nilai rata-rata tersebut kategori tuntas dan termasuk hasil yang bagus. Namun hasil pembelajaran PAI tersebut, tidak mencerminkan capaian kompetensi yang telah ditetapkan dalam kurikulum, hal ini terlihat pada ibadah peserta didik, seperti pelaksanaan shalat di sekolah, menunjukkan bahwa rata-rata peserta didik yang melaksanakan shalat zhuhur, baik sediri maupun berjamah di sekolah sekitar 70\%, ada sekitar 30\% peserta didik yang tidak melaksanakan shalat di sekolah dengan perilaku atau alasan seperti, ada yang sengaja menunda-nunda shalat, ada yang bermain, ngobrol dengan teman, bahkan ada yang berbohong kalau ia sudah shalat. Hal ini menunjukkan bahwa motivasi peserta didik untuk melaksanakan shalat tergolong masih rendah. Di samping itu, diakui atau tidak saat ini terjadi krisis moral yang nyata dan mengkhawatirkan di tengah masyarakat yang melibatkan peserta didik. Krisis moral itu antara lain kasus peserta

\footnotetext{
${ }^{2}$ Kementerian Pendidikan dan Kebudayaan, Model Silabus Mata Pelajaran Sekolah Menengah Pertama/Madrasah Tsanawiyah (SMP/MTs) Mata Pelajaran Pendidikan Agama Islam dan Budi Pekerti (Jakarta Kemendikbud RI, 2017).
} 
didik yang mempersekusi temannya, kebiasaan bullying di sekolah, bahkan sudah berani melawan dan menantang guru untuk berkelahi, belum lagi perilaku kenakalan peserta didik yang terjadi di beberapa tempat atau sekolah dan berlangsung terus menerus dan cenderung berulang-ulang seperti tawuran pelajar, pergaulan bebas dengan lawan jenis, geng motor pelajar, dan pengeroyokan senior kepada yunior yang sering berujung pada korban kematian. ${ }^{3}$

Persoalan tersebut muncul antara lain karena hasil pembelajaran PAI di sekolah belum mampu memberikan pemahaman, pembiasaan dan kesadaran terhadap kewajiban dan tanggung jawab untuk patuh dan taat pada aturan dan norma-norma agama, hal ini dipengaruhi oleh beberapa faktor: (1) kemampuan peserta didik bersifat heterogen, (2) waktu atau jam pelajaran agama Islam masih terbatas; (3) minat peserta didik lebih besar pada mata pelajaran lain; (4) sarana, prasarana dan media untuk penguatan pemahaman dan implementasi agama Islam masih terbatas; (5) penilaian hasil belajar PAI hanya diukur dengan berapa banyak hafalan materi pelajaran dan mengerjakan ujian tertulis di kelas yang dapat didemonstrasikan oleh peserta didik; dan (6) pendekatan dan metode dalam proses pembelajaran PAI di kelas cenderung menekankan lebih pada hafalan, dan cenderung pembelajaran sebatas teks, serta kurang mempersiapkan peserta didik untuk menyikapi dan menghadapi kehidupan yang nyata.

Capaian pembelajaran PAI tentu akan sulit dicapai jika sasaran, tujuan, materi dan metode pembelajaran yang merupakan instrumen paling penting dalam proses pembelajaran tidak sesuai dengan kondisi peserta didik. Berkaitan dengan masalah pembelajaran PAI tersebut, maka akan berdampak pada: pertama, rendahnya penghayatan dan pengamalan ibadah peserta didik, seperti motivasi untuk melaksanakan shalat, karena pendekatan dan metode pembelajaran PAI lebih banyak menghafal materi dari pada penghayatan, dan pengamalan ibadah dalam kaitannya dengan kehidupan sehari-hari. Kedua, rendahnya moralitas peserta didik juga salah satunya adalah karena kurangnya penghayatan dan pengamalan terhadap makna dan manafaat berbuat baik terhadap sesama, sebagaimana yang terkandung pada materi pelajaran PAI.

Untuk itu, diperlukan pendekatan dan metode dalam pembelajaran PAI yang dapat menanamkan pembiasaan dengan melibatkan peserta didik dalam memecahkan

\footnotetext{
${ }^{3}$ Wahyu Bagja Sulfemi \& Nova Mayasari, "Peranan Model Pembelajaran Value Clarification Technique Berbantuan Media Audio Visual Untuk Meningkatkan Hasil Belajar IPS," Jurnal Pendidikan, Vol. 20, No. 1 (2019): 53-68.
} 
masalah, namun tidak mengenyampingkan kemampuan berpikir sesuai dengan tingkat kecerdasan mereka. Pendekatan dan metode dalam pembelajaran tersebut adalah metode pembelajaran kontekstual. Dalam pembelajaran kontekstual, guru sebagai fasilitator bertanggung jawab dengan memberikan menstimulasi dan memotivasi, mendiagnosis dan mengatasi kesulitan, serta menyediakan pengalaman untuk menumbuhkan pemahaman peserta didik. ${ }^{4}$ Menurut Arsyad, bahwa salah satu persoalan tentang pencapaian hasil belajar adalah guru, masih banyak guru yang belum mampu mengembangkan dan menerapkan metodologi pembelajaran yang menarik, bervariasi sesuai dengan bidang atau topik dan usia peserta didik. Untuk itu, kompetensi guru mengajar akan memberikan dampak terhadap aspek kualitas kegiatan proses pembelajarannya, penguasaan materi seorang guru sangat berpengaruh dalam meningkatkan mutu proses pembelajaran di kelas. ${ }^{5}$

Dalam pembelajaran kontekstual dapat membantu guru untuk mengaitkan antara satu materi dengan materi yang diajarkannya dengan situasi dunia nyata untuk mendorong peserta didik membuat hubungan antara pengetahuan yang dimilikinya dengan penerapannya dalam kehidupan sehari. ${ }^{6}$ Dalam pembelajaran PAI pendekatan kontekstual diperlukan karena pada kenyataan bahwa sebagian besar peserta didik belum mampu menghubungkan antara apa yang mereka pelajari dengan manfaatnya dalam kehidupan nyata. Kondisi ini diasarkan pada pemahmahan pemahahaman yang didapat peserta didik belum sepenuhnya kebutuhan dalam praktek sehari-hari mereka. ${ }^{7}$ Sanjaya menyampaikan bahwa metode pembelajaran contextual teaching and learning (CTL) merupakan sebuah pendekatan pembelajaran yang menekankan keterlibatan

${ }^{4}$ Wahyu Bagja Sulfemi \& Yasinta Kamalia, "Jigsaw Cooperative Learning Model Using Audiovisual Media to Improve Learning Outcomes," Jurnal Pendidikan Sekolah Dasar ((JPsd), Vol. 6 No. 1 (2020): 30-42

${ }^{5}$ Arsyad \& Wahyu, "Pengembangan Keprofesian Berkelanjutan (PKB) bagi Guru Melalui Program Induksi Guru Pemula (PIGP)," Prosiding, Seminar Nasional tentang Pendidikan yang Diselenggarakan oleh STKIP Muhammadiyah Bogor, Tanggal 30 Maret 2016. (Bogor: STKIP Muhammadiyah, 2016), 38.

${ }^{6}$ Wahyu Bagja Sulfemi \& Nunung Yuliani, "Model Pembelajaran Contextual Teaching And Learning (CTL) Berbantu Media Miniatur Lingkungan untuk Meningkatkan Hasil Belajar IPS," Edunomic: Jurnal Ilmiah Pendidikan Ekonomi Fakultas Keguruan Dan Ilmu Pendidikan, Vol. 7, No. 2 (2019): 73-84.

${ }^{7}$ Wahyu Bagja Sulfemi \& Desi Yuliana, "Penerapan Model Pembelajaran Discovery Learning Meningkatkan Motivasi dan Hasil Belajar Pendidikan Kewarganegaraan," Jurnal Rontal Keilmuan Pancasila dan Kewarganegaraan, Vol. 5, No. 1 (2019): 17-30. 
peserta didik agar menemukan materi yang dipelajari dan menghubungkannya dengan situasi kehidupan nyata dalam kehidupan sehari-hari. ${ }^{8}$

Dari gambaran di atas, maka masalah tersebut penting untuk dilakukan penelitian dengan kegunaan untuk memperoleh pengetahuan tentang sejauhmana pengaruh pendekatan pembelajaran kontekstual pada pelajaran PAI yang dapat memberikan pengetahuan, pemahaman, dan pengamalan nilai-nilai ajaran Islam pada peserta didik, sehingga dapat berpengaruh dalam kehidupan. Berdasarkan hal tersebut, maka tujuan penelitian ini adalah untuk mengetahui: pertama, pengaruh pendekatan pembelajaran kontekstual pada pelajaran PAI terhadap motivasi shalat peserta didik. Kedua, pengaruh pendekatan pembelajaran kontekstual pada pelajaran PAI terhadap penguatan karakter peserta didik. Ketiga, pengaruh pendekatan pembelajaran kontekstual pada pelajaran PAI terhadap motivasi shalat dan penguatan karakter peserta didik.

\section{B. Kajian Literatur}

\section{Pendekatan Pembelajaran Kontekstual pada Pelajaran PAI}

Pendidikan merupakan sebuah proses yang bertujuan untuk memanusiakan manusia. Melalui pendidikan, diharapkan manusia mampu mengembangkan potensinya secara optimal melalui kemampuan berbahasa dan berpikir. Pendidikan sebagai usaha sadar mengarahkan perkembangan manusia yang bertujuan untuk mendewasakan manusia, agar mereka mampu menolong dirinya sendiri. ${ }^{9}$ Sasaran pembelajaran PAI secara teori maupun praktik harus mampu memberikan pandangan yang tepat dan terarah tentang kemungkinan-kemungkinan yang objektif dari proses pertumbuhan dan perkembangan peserta didik. Hal ini ditegaskan oleh Ibnu Sina dalam Abudin Nata, bahwa pendidikan dalam Islam harus diarahkan pada pengembangan seluruh potensi yang dimiliki seseorang kearah perkembangannya yang sempurna, yaitu perkembangan fisik, intelektual dan budi pekerti. ${ }^{10}$ Pendidikan dalam Islam harus diarahkan pada upaya mempersiapkan peserta didik agar dapat hidup di masyarakat secara bersama-

\footnotetext{
${ }^{8}$ Wina Sanjaya, Pembelajaran dalam Implementasi Kurikulum Berbasis Kompetensi (Bandung: Kencana, 2008), 109

${ }^{9}$ Arsyad \& Wahyu Bagja Sulfemi, "Pengaruh Kelompok Kerja Guru (KKG) terhadap Peningkatan Kompetensi Pedagogik dan Kemampuan Menulis Karya Ilmiah," Jurnal Pendidikan Dasar Indonesia Jurnal Pendidikan Dasar Indonesia (JPDI), Vol. 7, No. 2 (2019): 53-58.

${ }^{10}$ Abuddin Nata, Pemikiran Para Tokoh Pendidikan Islam, Seri Kajian Fisafat Pendidikan Islam (Jakarta: Raja Grafindo Persada 2000), 67
} 
sama dengan melakukan pekerjaan sesuai keahlian, bakat, kesiapan, kecenderungan dan potensi yang dimiliki. Sementara itu, Mulyo Ekosusilo menjelaskan bahwa tujuan utama PAI, bukan hanya knowing (mengetahui) tentang ajaran atau nilai-nilai Islam ataupun doing (bisa mempraktekkan apa yang diketahui), setelah diajarkan di sekolah, justru lebih mengutamakan being (beragama atau menjalani hidup atas ajaran nilai-nilai agama Islam), karena itu PAI harus lebih diorientasikan pada tataran moral action, yakni peserta didik tidak hanya berhenti pada tataran kompeten (competence), tetapi sampai memiliki kemauan (will) dan kebiasaan dalam mewujudkan ajaran-ajaran dan nilai-nilai agama Islam dalam kehidupan sehari-hari. ${ }^{11}$

Pendekatan dan metode pembelajaran kontekstual dapat mengembangkan potensi peserta didik dengan melibatkannya dalam proses pembelajaran di kelas dan mampu mengaitkannya dalam kehidupan sehari-hari melalui pembelajaran doing significant works. Hal ini mengacu pada penjelasan Eline B. yang mengemukakan komponen dalam pengembangan CTL yang harus diterapkan,......an educational process that aim to help student se meaningin the academic matrial they are studying by connecting academicsubjects with the context of their daily lives, that is, with context of their pesonal, social, and culture circuntance. to achieve this aim the system emcompasess the following eight components:making meaning connctions,doing significant work, self regulated learning, collaborating, critical and creative thinking, nurturung the individual, reaching high standars, using authntic assesment. ${ }^{12}$ Dengan pendekatan kontekstual, maka pembelajaran yang harus berlangasung adalah guru harus mampu menjelaskan dengan menghadirkan dunia nyata ke dalam kelas, yaitu mendorong peserta didik untuk membuat hubungan antara pengetahuan yang dimilikinya dengan penerapannya dalam kehidupan sehari-hari. Kegiatan pembelajaran berjalan secara alamiah dengan bekerja dan mengalami, tidak lagi hanya transfer pengetahuan dari guru kepada peserta didik.

Untuk itu, pendekatan dan metode pembelajaran kontekstual dalam PAI harus mampu menekankan pada proses keterlibatan peserta didik secara penuh untuk dapat memahami dan menemukan materi yang dipelajari dan dapat menghubungkannya

\footnotetext{
${ }^{11}$ Mulyo Ekosusilo, Hasil Penelitian Kualitatif Sekolah Unggul Berbasis Nilai (Sukoharjo: Univet Antara Press 2003), 58.

${ }^{12}$ Eline B. Jhonson, Contextual Teaching and Learning: What It Is and Why It's Here to Stay (California: Crown Press Inc. Thousand Oaks, 2002), 65.
} 
dengan situasi kehidupan nyata, sehingga peserta didik tergerak hatinya untuk menerapkannya dalam kehidupann sehari-hari. Dengan demikian, dalam kelas kontekstual, tugas guru adalah membantu peserta didik mencapai tujuannya, guru memberikan strategi bukan informasi, guru mengelola kelas guru menjadi tim untuk mengarahkan peserta didik dengan cara menemukan dan merasakan sendiri, bukan apa kata guru, melalui strategi pembelajaran: (1) mengamati dengan menyimak dan membaca materi pelajaran PAI; (2) bertanya, mengajukan pertanyaan tentang ketentuan terkait dengan materi pelajaran PAI; (3) eksperimen/explore, secara berkelompok mencari data atau informasi dan mendiskusikan tentang materi pelajaran PAI; (4) asosiasi, membuat analisis dan merumuskan tentang manfaat yang terkait dengan materi pelajaran PAI; dan (5) komunikasi, mendemonstrasikan, memaparkan rumusan hikmah dan manfaat yang terkait dengan materi pelajaran PAI dalam kehidupan sehari, serta mempraktekkan setiap hari.

\section{Penguatan Motivasi Shalat Peserta Didik Melalui Pembelajaran PAI}

Pada dasarnya motivasi adalah usaha yang didasari untuk mengerahkan dan menjaga tingkah laku seseorang agar ia terdorong untuk bertindak melakukan sesuatu sehingga mencapai hasil atau tujuan tertentu. Motivasi merupakan salah satu aspek psikis yang memiliki pengaruh terhadap pencapaian hasil belajar. Motivasi berarti segala sesuatu yang ditujukan untuk mendorong atau memberikan semangat kepada seseorang yang melakukan kegiatan agar menjadi lebih giat dalam kegiatannya atau untuk memperoleh hasil yang yang lebih baik. Ngalim Purwanto menjelaskan bahwa motivasi mengandung tiga komponen pokok, yaitu menggerakkan, mengarahkan, dan menopang tingkah laku manusia. Lebih lanjut dijelaskan bahwa: pertama, menggerakkan berarti untuk menimbulkan kekuatan pada individu, dan bertindak dengan cara tertentu. Kedua, mengarahkan atau menyalurkan tingkah laku, ia menyediakan suatu orientasi tujuan. Tingkah laku individu diarahkan terhadap sesuatu. Ketiga, menjaga atau menopang tingkah laku, lingkungan sekitar harus menguatkan intensitas dan arah dorongan dan kekuatan individu. ${ }^{13}$ Untuk itu, motivasi menjadi syarat mutlak dalam meningkatkan hasil belajar peserta didik yang terlihat pada aspek kognisi, afektif dan psikomotor. Kemampuan yang akan dicapai pada pelajaran PAI harus berorientasi pada perilaku afektif dan psikomotorik dengan dukungan

\footnotetext{
${ }^{13}$ Ngalim Purwanto, Psikologi Pendidikan (Bandung: PT. Remaja Rosda Karya 1998), 60
} 
pengetahuan kognitif dalam rangka memperkuat pelaksanaan ibadah dan penguatan karakter peserta didik.

Melalui kompetensi PAI tersebut, selain membekali peserta didik dengan pengetahuan agama, guru juga membiasakan peserta didik untuk melaksanakan praktek ibadah, hal ini dilakukan untuk memotivasi peserta didik agar berminat, senang dan rajin dalam melaksanakan ibadah khususnya shalat lima waktu, karena salah satu indikator tercapianya pembelajaran PAI adalah peserta didik mampu menjelaskan, mempraktikkan dan mengetahui hikmah melaksanakan shalat yang merupakan ibadah yang diwajibkan Allah SWT, bagi umat Islam laki-laki dan perempuan sebagai manifestasi keimanan seseorang hamba terhadap Khaliqnya.

Pendidikan agama Islam di sekolah harus melatih peserta didik untuk melakukan ibadah shalat, dan mengetahui hikmah yang terkandung dalam shalat, yaitu: pertama, disiplin waktu. Orang yang shalat tepat pada waktunya dapat dilihat dari sikapnya yang efektif menggunakan waktu. Kedua, cinta kebersihan. Shalat tidak sah bila tanpa bersuci. Ketiga, niat lurus karena Allah SWT. Seorang yang khusyu' shalatnya akan selalu menjaga niat dalam setiap perbuatannya. Keempat, cinta keteraturan. Shalat juga memiliki rukun yang tertib urutannya. Melalui hikmah shalat tersebut, maka dalam pembelajaran PAI, agar peserta didik dapat termotivasi untuk shalat. Untuk itu, melalui pendekatan kontekstual pada PAI, guru harus mampu menjelaskan materi agar peserta didik dapat memahami dan menemukan manfaat dan mengaitkan shalat dalam kehidupan seharti-hari, sehingga dapat menumbuhkan minatnya untuk mengerjakan shalat. Dengan memahami dan menemukan manfaat dan kaitan shalat dengan kehidupan seharti-hari, maka peserta didik menyadari pentingnya shalat sehingga ia terdorong untuk melaksanakannya. Dorongan tersebut bersumber dari dalam diri individu itu sendiri (motivasi intrinsik) yang diperkuat oleh oleh penjelasan guru (motivasi ekstrinsik). Bentuk motivasi peserta didik dalam melaksanakan shalat terlihat pada: (1) frekuensi shalat; (2) khusyu' dalam shalat (tidak bercanda); (3) menunaikan shalat tepat pada waktunya; dan (4) perubahan perilaku ke arah yang baik.

Langkah-langkah pelaksanaan pembelajarana PAI dengan pendekatan kontekstual pada materi shalat yaitu sebagai berikut: pertama, pendahuluan, meliputi: (1) menyiapkan peserta didik, (2) mengajukan pertanyaan yang berkaitan pengetahuan sebelumnya dan materi yang dipelajari; dan (3) menjelaskan dan menyampaikan tujuan 
dan cakupan pembelajaran. Kedua, inti pembelajaran, meliputi: (1) menyimak, menyimak dan membaca penjelasan mengenai materi shalat wajib; (2) bertanya, mengajukan pertanyaan tentang manfaat shalat berjamaah dalam kehidupan; (3) eksperimen/explore, secara berkelompok mencari contoh nyata tentang manfaat shalat berjamaah dalam kehidupan dan mendiskusikannya; (4) asosiasi, menganalisis kegiatan manfaat shalat berjamaah kaitannya dalam kehidupan sehari-hari; dan (5) komunikasi, memaparkan hubungan antara manfaat shalat baik berjamaah maupun sendiri-sendiri dalam kehidupan sehari-hari, mendemontrasikan contoh shalat, serta memberikan catatan hasil hasil pelaksanaan shalat baik berjamaah maupun sendiri-sendiri, baik di sekolah, rumah atau di masyarakat secara individu. Ketiga, penutup pembelajaran, meliputi: (1) membuat rangkuman/simpulan; (2) penilaian dan/atau refleksi, memberikan umpan; (3) merencanakan kegiatan tindak lanjut; dan (4) menyampaikan rencana pembelajaran pada pertemuan berikutnya. Keempat, evaluasi akhir pembelajaran, meliputi: (1) fortofolio, paparan tentang manfaat dan hikmah shalat dalam kehidupan sehari-hari dan catatan kegiatan pelaksanaan shalat lima waktu, baik di sekolah, rumah maupun di mayarakat; dan (2) tes kemampuan kognitif.

Dengan demikian, melalui metode pembelajaran kontekstual pada pembelajaran PAI, maka diyakini akan tertanam pengetauan, penghayatan dan kebiasaan sehingga mendorong peserta didik untuk selalu melaksanakan shalat lima waktu baik di sekolah, masyarakat maupun di rumah, yang diukur melalui: (1) melaksanakan shalat lima waktu setiap hari; (2) khusyu' dalam shalat (tidak bercanda pada saat shalat); (3) segera melaksanakan shalat pada waktunya (tidak menunda-nunda shalat); dan (4) memperlihatkan perubahan perilaku yang baik.

\section{Penguatan Karakter Peserta Didik melalui Pembelajaran PAI}

Karakter adalah watak, tabiat, akhlak, atau kepribadian seseorang yang terbentuk dari hasil internalisasi berbagai kebajikan (virtues) yang diyakini dan digunakan sebagai landasan untuk cara pandang, berpikir, bersikap, dan bertindak. Kebajikan terdiri atas sejumlah nilai, moral, dan norma, seperti jujur, berani bertindak, dapat dipercaya, dan hormat kepada orang lain. ${ }^{14}$ Individu yang berkarakter baik merupakan seseorang yang berusaha melakukan hal-hal yang terbaik terhadap Allah SWT, dirinya, sesamanya,

\footnotetext{
${ }^{14}$ Pusat Kurikulum, Penguatan Metodologi Pembelajaran Berdasarkan Nilai-Nilai Budaya untuk Membentuk Daya Saing dan Karakter Bangsa Pengembangan Pendidikan Budaya dan Karakter Bangsa. (Jakarta: Pusat Kurikulum, Balitbang, Kemdiknas, 2010), 46
} 
lingkungannya, dengan mengoptimalkan potensi (pengetahuan) dirinya dan disertai dengan kesadaran, emosi dan motivasinya serta perasaannya.

Penanaman pendidikan karakter tidak bisa hanya sekedar mentansfer ilmu pengetahuan atau melatih keterampilan tertentu. Penanaman pendidikan karakter perlu proses, contoh teladan, dan pembiasaan dalam lingkungan sekolah, keluarga, lingkungan masyarakat maupun lingkungan media massa. Karakter merupakan sifat alami seseorang dalam merespons situasi secara bermoral. Sifat alami itu dimanifestasikan dalam tindakan nyata menjadi tingkah laku yang baik, jujur, bertanggung jawab, menghormati orang lain dan karakter mulia lainnya. ${ }^{15}$ Sebagai tindak lanjut penguatan karakter, pemerintah telah merumuskan lima nilai utama karakter yang saling berhubungan, yaitu: (1) relegius; (2) nasionalis; (3) mandiri; (4) gotong royong; dan (5) integritas. ${ }^{16}$ Karakter atau akhlak mulia harus dibangun, sedangkan membangun akhlak mulia membutuhkan sarana yang salah satunya adalah jalur pendidikan. Melalui pendidikan akan mampu membentuk karakter dan membangun akhlak mulia para peserta didik. Untuk itu, sekolah memiliki tanggungjawab untuk bisa menanamkan nilai-nilai tersebut terhadap semua peserta didik, melalui proses pembelajaran di dalam kelas maupun di luar kelas.

Salah satu alternatif yang dapat dilakukan dalam melaksanakan pendidikan karakter di sekolah adalah dengan mengoptimalkan pembelajaran materi pendidikan agama Islam (PAI). Peran pendidikan agama khususnya pendidikan agama Islam sangat strategis dalam mewujudkan pembentukan karakter peserta didik. Dalam panduan penyusunan penguatan pendidikan karakter (PPK) peserta didik, dirumuskan berbasis kelas, yaitu: (1) memahami pentingnya penguatan pendidikan karakter dalam proses belajar mengajar di kelas; (2) menyadari pentingnya mengembangkan karakter siswa melalui mata pelajaran maupun tema; (3) menyadari pentingnya mengembangkan karakter siswa melalui metode mengajar yang dipilih; (4) menyadari pentingnya mengembangkan karakter siswa melalui pengelolaan kelas; (5) mampu memodelkan proses belajar mengajar yang sekaligus menguatkan pendidikan karakter siswa melalui mata pelajaran atau tema, metode mengajar, dan pengelolaan kelas. ${ }^{17}$ Melalui

\footnotetext{
${ }^{15}$ Agus Wibowo, Pendidikan Karakter: Strategi Membangun Karakter Bangsa Berperadaban (Yogyakarta: Pustaka Pelajar 2012), 54.

${ }^{16}$ Tim Penyusun PPK, Panduan Penilaian Penguatan Pendidikan Karakter Tingkat Sekolah Dasar dan Sekolah Menengah Pertama (Jakarta: Kementerian Pendidikan dan Kebudayaan RI. 2016), 13.

${ }^{17}$ Ibid., 15.
} 
pendidikan karakter pada pelajaran PAI, peserta didik diharapkan mampu secara mandiri untuk meningkatkan dan menggunakan pengetahuannya, mengkaji dan menginternalisasikan serta mempersonalisasikan (kepribadian) nilai-nilai karakter dan akhlak mulia sehingga terwujud dalam perilaku kehidupan sehari-hari.

Untuk itu, implementasi pendidikan karakter harus sejalan dengan orientasi pendidikan, yaitu pola pembelajaran dan pendekatannya dilakukan dengan cara menanamkan nilai-nilai moral dalam diri peserta didik yang bermanfaat bagi perkembangan pribadinya sebagai makhluk individual dan sosial, baik di sekolah maupun di masyarakat. Pendidikan agama merupakan basis dari pendidikan karakter. Hal tersebut tidak terlepas dari muatan nilai-nilai pendidikan karakter yang mengambil dari pendidikan agama. Di dalam pendidikan karakter tersimpan pembelajaran akhlak mulia yang mencakup etika (baik-buruk, hak-kewajiban), budi pekerti (tingkah laku), dan moral (baik buruk menurut umum) sebagai perwujudan dari keimanan dan ketakwaan terhadap Tuhan Yang Maha Esa. ${ }^{18}$

Merujuk pada kompetensi inti dalam silabus mata pelajaran PAI, yaitu; menghargai, dan menghayati perilaku jujur, disiplin, tanggung jawab, peduli (toleransi, gotong royong), santun, percaya diri, dalam berinteraksi secara efektif dengan lingkungan sosial dan alam dalam jangkauan pergaulan dan keberadaannya, maka indikator ukuran penguatan karakter peserta didik pada PAI dengan kompetensi dasar yaitu: perilaku jujur, perilaku hormat dan patuh kepada orang tua dan guru serta perilaku empati terhadap sesama. Langkah-langkah penerapan metode pembelajarana kontekstual pada materi PAI yaitu sebagai berikut: (1) menyimak dan membaca penjelasan tentang materi perilaku jujur, perilaku hormat dan patuh kepada orang tua dan guru serta perilaku empati terhadap sesama; (2) bertanya, mengajukan pertanyaan tentang manfaat tentang materi perilaku jujur, perilaku hormat dan patuh kepada orang tua dan guru serta perilaku empati terhadap sesama; (3) eksperimen/explore, secara berkelompok mencari contoh nyata tentang tentang materi perilaku jujur, perilaku hormat dan patuh kepada orang tua dan guru serta perilaku empati terhadap sesama melalui berbagai sumber; (4) asosiasi, tentang perilaku jujur, perilaku hormat dan patuh kepada orang tua dan guru serta perilaku empati terhadap sesama dalam kehidupan sehari-hari; (5) komunikasi, memaparkan hubungan tentang perilaku jujur, perilaku

\footnotetext{
${ }^{18}$ Badan Standar Nasional Pendidikan, Panduan Penilaian Kelompok Mata Pelajaran Agama dan Akhlak Mulia (Jakarta: Depdiknas, 2009), 9
} 
hormat dan patuh kepada orang tua dan guru serta perilaku empati terhadap sesama dengan kehidupan sehari-hari, dan memberikan catatan hasil perilaku jujur, perilaku hormat dan patuh kepada orang tua dan guru serta perilaku empati terhadap sesama dalam kehidupan sehari-hari. Dengan demikian, melalui pembelajaran PAI pendekatan kontektual, maka diharapkan peserta didik memiliki pengetahuan dan pembiasaan untuk beperilaku jujur, perilaku hormat dan patuh kepada orang tua dan guru serta perilaku empati terhadap sesama yang tercermin dalam kehidupan sehari-hari.

\section{Metode}

Kegiatan penelitian sebagai suatu cara dalam memperoleh pengetahuan atau memecahkan masalah yang dihadapi yang dilakukan secara ilmiah, sistematis dan logis dalam menempuh langkah-langkah tertentu. ${ }^{19}$ Penelitian ini dilaksanakan di Sekolah Menengah Pertama Negeri di Kecamatan Leuwiliang Kabupaten Bogor pada tahun pelajaran 2018/2019. Waktu pelaksanaan penelitian selama 11 bulan dari Juli 2018 sampai dengan Mei 2019. Populasi penelitian adalah seluruh peserta didik kelas 7 SMP Negeri 1 Leuwiliang dengan jumlah 5 rombongan belajar dengan jumlah siswa 150 orang, SMP Negeri 2 Leuwiliang dengan jumlah 4 rombongan belajar dengan jumlah siswa 120 orang, SMP Negeri 3 Leuwiliang dengan jumlah 4 rombongan belajar dengan jumlah siswa 120 orang, sehingga jumlah keseluruhan populasi 396 siswa. Jumlah sampel diambil yang yaitu 10\%, sehingga jumlah sampel 40 orang siswa dengan menggunakan teknik pengambilan sampel secara acak dari jumlah populasi yang ada, atau simple random sampling.

Metode yang digunakan adalah metode deskriptif yaitu membuat deskriptif secara sistematis, faktual dan akurat mengenai fakta-fakta serta hubungan antar fenomena yang diselidiki, dengan tujuan untuk menguji hipotesis yang menyatakan ada apakah terdapat hubungan atau tidak terdapat antara setiap variabel baik antara bebas $\left(\mathrm{X}_{1}\right)$ dan $\left(\mathrm{X}_{2}\right)$ dengan variabel terikat $(\mathrm{Y})$. Analisis data yang digunakan adalah analisis regresi dan korelasi. Analisis regresi yaitu ingin menguji apakah ada atau tidak ada pengaruh antara variabel yang diteliti. Sedangkan analisis korelasi ingin mengetahui seberapa besar tingkat keeratan pengaruh antar variabel $\mathrm{Y}$ dengan variable $\mathrm{X}$ dan agar hasil keputusannya dapat dipertanggungjawabkan, maka koefisien korelasi perlu diuji signifikansinya.

\footnotetext{
${ }^{19}$ Arsyad, "Hubungan Antara Capaian Pembelajaran Dasar-Dasar Penelitian dan Statistik dengan Mutu Skripsi: Studi Analisis di STKIP Muhammadiyah Bogor," Jurnal Ilmiah Kependidikan, Vol. XII, No. 2 (2019): 6
} 


\section{Temuan dan Pembahasan}

\section{Penguatan Motivasi Shalat dan Karakter Siswa Melalui Pendekatan Pembelajaran Kontekstual Pada Mata Pelajaran PAI}

Analisis penelitian ini untuk membuktikan hipotesis yang diajukan: pertama, bahwa dari hasil analisis regresi dan korelasi diperoleh bahwa metode pembelajaran kontekstual pada PAI (Y) berpengaruh terhadap motivasi shalat peserta didik $\left(\mathrm{X}_{1}\right)$ yang digambarkan dengan persamaan $\hat{Y}=0,622+0,332 X_{1}$. Persamaan regresi tersebut dapat digunakan sebagai alat untuk menjelaskan dan mengambil kesimpulan mengenai metode pembelajaran kontekstual pada PAI (Y) dengan penguatan motivasi shalat peserta didik $\left(\mathrm{X}_{1}\right)$. Persamaan ini memiliki arti bahwa setiap kenaikan satu unit metode pembelajaran kontekstual pada PAI akan meningkatkan 0,322 pengutan motivasi shalat peserta didik dengan konstanta 0,622. Selanjutnya dari hasil analisis uji t, diperoleh $t_{\text {hitung }}$ sebesar 5,383 dan $t_{\text {tabel }}$ sebesar 2,02, karena $t_{\text {hitung }}>t_{\text {tabel, }}$, yaitu 5,383>2,02, dengan koefisien determinasi sebesar 0,4343 yang menerangkan bahwa 43,43\% variansi variabel motivasi shalat siswa ditentukan oleh variabel metode kontekstual pada PAI. Kesimpulkan hipotesis $\mathrm{H}$ nol $\left(\mathrm{H}_{0}\right)$ yang diajukan bahwa terdapat pengaruh metode pembelajaran kontekstual pada PAI terhadap penguatan motivasi shalat peserta didik dapat diterima. Artinya bahwa metode pembelajaran kontekstual memberikan pengaruh positif terhadap penguatan motivasi peserta didik untuk melaksanakan shalat. Kedua, bahwa dari hasil analisis regresi dan korelasi diperoleh bahwa metode pembelajaran kontekstual pada PAI (Y) berpengaruh terhadap penguatan katrakter peserta didik $\left(\mathrm{X}_{2}\right)$

yang digambarkan dengan persamaan $\hat{\mathrm{Y}}=-2,920+0,390 \mathrm{X}_{2}$. Persamaan regresi tersebut dapat digunakan sebagai alat untuk menjelaskan dan mengambil kesimpulan mengenai metode kontektual pada PAI ( $\mathrm{Y})$ dengan penguatan karakter peserta didik $\left(\mathrm{X}_{2}\right)$. Persamaan ini memiliki arti setiap kenaikan satu unit metode pembelajaran kontekstual pada PAI akan meningkatkan 0,390 unit penguatan karakter peserta didik dengan konstanta -2,920. Artinya, metode pembelajaran kontekstual pada PAI (Y) berpengaruh terhadap penguatan karakter peserta didik $\left(X_{2}\right)$, karena $t_{\text {hitung }}>t_{\text {tabel }}$, yaitu 4,971 $>2,02$. Koefisien determinasi sebesar 0,3944 menerangkan bahwa 39,44\% variansi penguatan karakter peserta didik ditentukan oleh variabel metode kontekstual pada PAI. Dengan demikian, bahwa hipotesis $\mathrm{H}$ nol $\left(\mathrm{H}_{\mathrm{o}}\right)$ yang diajukan terdapat pengaruh metode pembelajaran kontektusal pada PAI terhadap penguatan karakter peserta didik dapat 
diterima. Artinya bahwa metode kontekstual memberikan pengaruh positif terhadap penguatan karakter peserta didik. Ketiga, bahwa dari hasil analisis regresi dan korelasi diperoleh bahwa metode pembelajaran kontekstual pada PAI (Y) berpengaruh terhadap penguatan motivasi shalat peserta didik dan penguatan karakter peserta didik $\left(\mathrm{X}_{2}\right)$ yang digambarkan dengan persamaan garis regresi $\hat{Y}=-14,424+0,253 X_{1}+0,284 X_{2}$. Perhitungan korelasi ganda $\mathrm{X}_{1}$ dan $\mathrm{X}_{2}$ dengan $\mathrm{Y}$ tersebut untuk menguji keberartian koefisien korelasi ganda, dapat dilihat pada $F_{\text {hitung }}=29,89$ sedangkan $F_{\text {tabel }}$ dengan pembilang 2 dan dk pembilang 37 pada taraf signifikan $\alpha 0,05$ sebesar 3,25 Oleh karena $\mathrm{Fh}>\mathrm{Ft}$, ini menunjukkan bahwa terdapat pengaruh antara penerapan metode kontekstual pada PAI dengan penguatan motivasi shalat dan karakter peserta didik. Koefisien determinasi $\left(\mathrm{R}^{2}\right.$ adalah sebesar 0,786). Ini menunjukkan bahwa $78,90 \%$ peningkatkan penguatan motivasi shalat peserta didik dan penguatan karakter peserta didik dipengaruhi oleh metode pembelajaran kontekstual pada PAI secara bersamasama, melalui persamaan regresi $\hat{Y}=-14,424+0,253 X_{1}+0,284 X_{2}$. Simpulan dari hipotesis $\mathrm{H}$ nol $\left(\mathrm{H}_{\mathrm{o}}\right)$ yang diajukan terdapat pengaruh metode pembelajaran kontekstual pada PAI terhadap penguatan motivasi shalat dan penguatan karakter peserta didik dapat diterima. Artinya bahwa metode pembelajaran kontekstual memberikan pengaruh positif terhadap penguatan motivasi shalat dan penguatan karakter peserta didik.

\section{Pembahasan Hasil Penelitian}

Merujuk pada hasil uji regresi dan korelasi, maka penelitian ini dapat diartikan bahwa: pertama, terdapat pengaruh positif antara variabel metode pembelajaran kontekstual pada PAI (Y) terhadap penguatan motivasi shalat peserta didik $\left(\mathrm{X}_{1}\right)$. Kedua, terdapat pengaruh positif antara variabel metode pembelajaran kontekstual pada PAI (Y) terhadap penguatan karakter peserta didik $\left(\mathrm{X}_{2}\right)$. Ketiga, terdapat pengaruh positif antara variabel metode pembelajaran kontekstual pada PAI (Y) terhadap penguatan motivasi shalat peserta didik $\left(\mathrm{X}_{1}\right)$ dan penguatan karakter peserta didik $\left(\mathrm{X}_{2}\right)$. Untuk mencapai tujuan tersebut dengan baik, maka diperlukan beberapa faktor. Di antara faktor terpenting dalam proses pembelajaran adalah faktor guru dan metode pembelajaran yang digunakan di kelas. Menurut Arsyad dan Salahudin bahwa untuk mendapatkan hasil belajar yang maksimal tidak terlepas dari dua faktor utama, yaitu faktor internal antara lain motivasi atau minat siswa dalam belajar, dan faktor eksternal 
sekolah melalui program guru dan keluarga melalui bimbingan orang tua. ${ }^{20}$ Keterlibatan guru dalam memberikan pengajaran, bimbingan dan contoh tauladan mendorong siswa untuk memahami, mengetahui dan mengamalkan apa yang dilihat dan dirasakan dalam kehidupan sehari-hari, seperti dorongan untuk melaksanakan shalat lima waktu dan dorongan untuk berprilaku baik. Untuk itu, guru harus harus menggunakan pendekatan yang tepat agar materi PAI mudah dipahami dan dimengerti oleh siswa, salah satunya pendekatan pembelajaran kontekstual. Sementara Yuliharti menyampaikan bahwa implikasi pola pembentukan karakter Islami yang telah dilakukan oleh Rasulullah SAW pada jalur pendidikan nonformal, yaitu: (1) memfungsikan masjid sebagai pusat kegiatan jalur pendidikan non formal; (2) pembina, pelaksana kegiatan seharusnya orang-orang yang berkarakter dan hatinya terpaut pada masjid; (3) orientasi kegiatan seharusnya mengarah pada masalah iman, akhlak, ilmu dan amal; (4) membentuk perkumpulan, organisasi sosial yang Islami dan dipelopori oleh kaum muda muslim dan bersinergi dengan pembentukan karakter dalam keluarga dan masyarakat. ${ }^{21}$

Perlunya pendekatan kontekstual dalam pembelajaran, khususnya pada mata pelajaran PAI, karena selama ini dalam pembelajaran belum didasarkan pada kenyataan bahwa sebagian besar peserta didik tidak mampu menghubungkan antara apa yang mereka pelajari dengan bagaimana pemanfaatannya dalam kehidupan nyata, karena pola pendekatan dan startegi pembelajaran tidak tepat. Dengan pendekatan kontekstual peserta didik diharapkan memiliki kemampuan untuk meningkatkan keimanan, pemahaman, penghayatan, dan pengamalan terhadap agama Islam, sehingga menjadi manusia muslim yang beriman dan bertakwa kepada Allah SWT. serta berakhlak mulia dalam kehidupan pribadi, dan bermasyarakat, antara lain tercermin pada motivasi melaksanakan shalat lima waktu sebagai kewajiban seorang muslim yang sudah baligh dan perilaku jujur, perilaku hormat dan patuh kepada orang tua dan guru serta perilaku empati terhadap sesama dalam kehidupan sehari-hari. Hal ini sejalan dengan hasil penelitian Wahyu yang menjelaskan bahwa peserta didik yang memiliki disiplin ibadah shalat yang baik akan selalu ingat kepada Allah yang memberikan hidup dan kehidupan. Mengingat Allah akan menghindarkan dari segala bentuk kemalasan

\footnotetext{
${ }^{20}$ Arsyad \& Salahudin, "Hubungan Kemampuan Membaca al-Qur'an dan Minat Belajar Siswa dengan Hasil Belajar Pendidikan Agama Islam (PAI)," EDUKASI: Jurnal Penelitian Pendidikan Agama dan Keagamaan, Vol. 16. No. 2 (2018): 179-190.

${ }^{21}$ Yuliharti, "Pembentukan Karakter Islami dalam Hadis dan Implikasinya pada Jalur Pendidikan Non Formal,” POTENSIA: Jurnal Kependidikan Islam, Vol. 4, No. 2 (2018): 216-228.
} 
dan kelesuan, serta rasa tidak tenang dan ketakutan saat melakukan kesalahan dan kelalaian dalam menjalankan kewajiban sehingga peserta didik dapat konsentrasi peserta didik dalam belajar. ${ }^{22}$

Dengan demikian, bahwa pendekatan kontekstual dalam pembelajaran PAI di sekolah memberikan pengetahuan, penghayatan serta mendorong peserta didik untuk mempraktekkan dan mengaitkannya dalam kehidupan sehari-hari, karena merasakan hikmah dan manfaatnya dalam kehidupan nyata, hal ini terlihat pada peningkatan pelaksanaan ibadah shalat dan perilaku jujur, perilaku hormat dan patuh kepada orang tua dan guru serta perilaku empati terhadap sesama juga terlihat semakin baik. Hal ini sejalan yang diungkapkan Amril, bahwa pendidikan Islam baik sebagai kelembagaan maupun mata pelajaran atau mata kuliah termasuk penelitian-penelitian dan pengembangan ilmu-ilmu keIslaman khususnya yang berparadigma epistemologis integratif-interkonektif menjadi instrumen yang strategis guna mengungkap pesan-pesan ideal moral dalam Islam, kemudian menggapainya sehingga damai-mendamaikan nasehat-menasehati yang terlepas dari dominasi dan represif sebagai bentuk nyata watak Islam rahmatan lil al'alamin dalam realitas sosial kehidupan semakin fungsional. ${ }^{23}$ Dengan demikian, bahwa pembelajaran yang dirancang untuk mengembangkan kompetensi yang utuh antara pengetahuan, keterampilan, dan sikap, maka peserta didik tidak hanya diharapkan bertambah pengetahuan dan wawasannya, tetapi juga meningkat kecakapan dan keterampilannya serta semakin mulia karakter dan kepribadiannya.

\section{E. Simpulan dan Saran}

\section{Simpulan}

Merujuk pada hasil hasil analisis data, maka penelitian ini dapat diartikan bahwa: pertama, terdapat pengaruh metode pembelajaran kontekstual pada PAI terhadap penguatan motivasi shalat peserta didik. Dengan demikian, dapat disimpulkan hipotesis $\mathrm{H}$ nol $\left(\mathrm{H}_{0}\right)$ yang diajukan dapat di terima. Kedua, terdapat pengaruh metode pembelajaran kontekstual pada PAI terhadap penguatan karakter peserta didik. Dengan demikian dapat di simpulkan bahwa hipotesis $\mathrm{H}$ nol $\left(\mathrm{H}_{\mathrm{o}}\right)$ yang diajukan dapat diterima.

\footnotetext{
${ }^{22}$ Wahyu Bagja Sulfemi, "Pengaruh Disiplin Ibadah Sholat, Lingkungan Sekolah, dan Intelegensi Terhadap Hasil Belajar Peserta Didik Mata Pelajaran Pendidikan Agama Islam," EDUKASI: Jurnal Penelitian Pendidikan Agama dan Keagamaan, Vol. 16. No. 2 (2018): 166-178.

${ }^{23}$ Amril M, "Islam Normatif Dan Historis (Faktual): Ziarah Epistemologi Integratif-Interkonektif dalam Pendidikan,” POTENSIA: Jurnal Kependidikan Islam, Vol. 5, No. 1 (2019): 78-98
} 
Ketiga, terdapat pengaruh metode pembelajaran kontekstual pada PAI terhadap penguatan motivasi shalat dan penguatan karakter peserta. Dengan demikian dapat di simpulkan bahwa hipotesis $\mathrm{Ha}$ nol $\left(\mathrm{H}_{\mathrm{o}}\right)$ yang diajukan dapat diterima. Dengan pendekatan kontekstual dalam pembelajaran PAI di sekolah memberikan pengetahuan, penghayatan serta mendorong peserta didik untuk mempraktekkan dan mengaitkannya dalam kehidupan sehari-hari, karena merasakan hikmah dan manfaatnya dalam kehidupan nyata, hal ini terlihat pada peningkatan pelaksanaan ibadah shalat dan perilaku jujur, perilaku hormat dan patuh kepada orang tua dan guru serta perilaku empati terhadap sesama juga terlihat semakin baik.

\section{Saran}

Dari hasil penelitian dan pembahasan, maka ada beberapa saran yang disampaikan, yaitu: pertama, bahwa pembelajaran PAI di sekolah tidak hanya disampaikan dan diukur pada aspek kognitif dengan bentuk penilaian angka-angka, tetapi pembelajaran PAI harus disampaikan dan diukur dengan menanamkan nilai-nilai keagamaan dan sejauhmana pengamalannya dalam kehidupan sehari-hari. Kedua, penguatan motivasi shalat dan karakter peserta didik melalui PAI sangat relevan, untuk itu, guru PAI di sekolah hendaknya memperhatikan metode dan pendekatan yang cocok dengan materi pelajaran PAI, terutama metode yang dapat menumbuhkan pemahaman sekaligus mampu mempraktekkannya dalam kehidupan sehari-hari. Ketiga, dalam implementasi metode pembelajaran kontekstual pada PAI, guru hendaknya menerapkan pengelolaan pembelajaran dengan pendekatan; mengamati, bertanya, eksperimen/ explore, asosiasi dan komunikasi, sehingga peserta didik mampu merumuskan hikmah dan manfaat shalat dan perbuatan baik dalam kehidupan, serta dapat mempraktekkannya setiap hari, baik di sekolah, rumah maupun di lingkungan masyarakat.

\section{F. Daftar Pustaka}

Amril M. "Islam Normatif Dan Historis (Faktual): Ziarah Epistemologi IntegratifInterkonektif dalam Pendidikan," POTENSIA: Jurnal Kependidikan Islam, Vol. 5 No. 1 (2019): 78-98.

Arsyad \& Salahudin. "Hubungan Kemampuan Membaca al-Qur'an dan Minat Belajar Siswa dengan Hasil Belajar Pendidikan Agama Islam (PAI)." EDUKASI: Jurnal Penelitian Pendidikan Agama dan Keagamaan, Vol. 16, No. 2 (2018): 179-190. 
Arsyad \& Wahyu Bagja Sulfemi. "Pengaruh Kelompok Kerja Guru (KKG) terhadap Peningkatan Kompetensi Pedagogik dan Kemampuan Menulis Karya Ilmiah." Jurnal Pendidikan Dasar Indonesia Jurnal Pendidikan Dasar Indonesia (JPDI), Vol. 7, No. 2 (2019): 53-58.

Arsyad \& Wahyu. "Pengembangan Keprofesian Berkelanjutan (PKB) Bagi Guru Melalui Program Induksi Guru Pemula (PIGP)." Prosiding. Seminar Nasional STKIP Muhammadiyah Bogor, (2) 2016.

Arsyad. "Hubungan antara Capaian Pembelajaran Dasar-Dasar Penelitian dan Statistik dengan Mutu Skripsi: Studi Analisis di STKIP Muhammadiyah Bogor.” Jurnal Ilmiah Kependidikan, Vol. 12, No. 2 (2019): 6.

Badan Standar Nasional Pendidikan. Panduan Penilaian Kelompok Mata Pelajaran Agama dan Akhlak Mulia. Jakarta: Depdiknas, 2009

Ekosusilo, Mulyo. Hasil Penelitian kualitatif Sekolah Unggul Berbasis Nilai. Sukoharjo: Univet Antara Press, 2003.

Jhonson, Eline B. Contextual Teaching and Learning: What It Is and Why It's Here to Stay. California: Crowin Press Inc. Thousand Oaks, 2002.

Kementerian Pendidikan dan Kebudayaan RI. Panduan Penilaian Penguatan Pendidikan Karakter Tingkat Sekolah Dasar dan Sekolah Menengah Pertama. Jakarta: Tim Penyusun PPK Kementerian Pendidikan dan Kebudayaan RI. 2016.

Kementerian Pendidikan dan Kebudayaan. Model Silabus Mata Pelajaran Sekolah Menengah Pertama/Madrasah Tsanawiyah (SMP/MTs) Mata Pelajaran Pendidikan Agama Islam dan Budi Pekerti. Jakarta Kemendikbud RI, 2017.

Kementerian Pendidikan Nasional. Penguatan Metodologi Pembelajaran Berdasarkan Nilai-Nilai Budaya untuk Membentuk Daya Saing dan Karakter Bangsa Pengembangan Pendidikan Budaya dan Karakter Bangsa. Jakarta: Pusat Kurikulum, Balitbang, Kemdiknas, 2010.

Nata, Abuddin. Pemikiran Para Tokoh Pendidikan Islam, Seri Kajian Fisafat Pendidikan Islam. Jakarta: Raja Grafindo Persada, 2000.

Purwanto, Ngalim. Psikologi Pendidikan. Bandung: PT. Remaja Rosda Karya, 1998.

Republik Indonesia. Undang-undang Republik Indonesia Nomor 20 Tahun 2003. Sistem Pendidikan Nasional. Jakarta: Lembaran Negara 2003.

Sanjaya, Wina. Pembelajaran dalam Implementasi Kurikulum Berbasis Kompetensi. Bandung: Kencana, 2008.

Sulfemi, Wahyu Bagja \& Desi Yuliana. "Penerapan Model Pembelajaran Discovery Learning Meningkatkan Motivasi Dan Hasil Belajar Pendidikan Kewarganegaraan.” Jurnal Rontal Keilmuan Pancasila dan Kewarganegaraan, Vol. 5, No. 1 (2019): 17-30.

Sulfemi, Wahyu Bagja \& Nova Mayasari. "Peranan Model Pembelajaran Value Clarification Technique Berbantuan Media Audio Visual Untuk Meningkatkan Hasil Belajar IPS.” Jurnal Pendidikan, Vol. 20, No. 1 (2019): 53-68. 
Sulfemi, Wahyu Bagja \& Nunung Yuliani. "Model Pembelajaran Contextual Teaching And Learning (CTL) Berbantu Media Miniatur Lingkungan Untuk Meningkatkan Hasil Belajar IPS." Edunomic: Jurnal Ilmiah Pendidikan Ekonomi Fakultas Keguruan Dan Ilmu Pendidikan, Vol. 7, No. 2 (2019): 7384.

Sulfemi, Wahyu Bagja \& Yasinta Kamalia. "Jigsaw Cooperative Learning Model Using Audiovisual Media To Improve Learning Outcomes." JPsd (Jurnal Pendidikan Sekolah Dasar), Vol. 6, No. 1 (2020): 30-42.

Sulfemi, Wahyu Bagja. "Pengaruh Disiplin Ibadah Sholat, Lingkungan Sekolah, dan Intelegensi Terhadap Hasil Belajar Peserta Didik Mata Pelajaran Pendidikan Agama Islam." EDUKASI: Jurnal Penelitian Pendidikan Agama dan Keagamaan, Vol. 16. No. 2 (2018): 166-178.

Wibowo, Agus. Pendidikan Karakter: Strategi Membangun Karakter Bangsa Berperadaban. Yogyakarta: Pustaka Pelajar, 2012.

Yuliharti, "Pembentukan Karakter Islami dalam Hadis dan Implikasinya pada Jalur Pendidikan Non Formal." POTENSIA: Jurnal Kependidikan Islam, Vol. 4, No. 2 (2018): 216-228. 